\title{
OPTIMASI PENJADWALAN PENGERJAAN SOFTWARE PADA SOFTWARE HOUSE DENGAN FLOW-SHOP PROBLEM MENGGUNAKAN ARTIFICIAL BEE COLONY
}

\author{
Muhammad Fhadli ${ }^{1}$, Daneswara Jauhari², Dhimas Anjar Prabowo ${ }^{3}$, Anang Hanafi ${ }^{4}$, Aryeswara Sunaryo ${ }^{5}$, \\ Imam Cholissodin' \\ 1,2,3,4,5,6 Fakultas Ilmu Komputer, Universitas Brawijaya \\ Email: ${ }^{1}$ muhammadfhadli20@gmail.com ${ }_{2}^{2}$ daneswarajauhari@gmail.com, ${ }^{3}$ dhimasanjar@gmail.com, \\ 4ananghanafi13@gmail.com, 5ary3swara@gmail.com,6imamcs@ub.ac.id
}

(Naskah masuk: 1 Oktober 2016, diterima untuk diterbitkan: 26 Desember 2016)

\begin{abstract}
Abstrak
Penelitian ini mengusulkan sebuah implementasi terkait optimasi penjadwalan pengerjaan software pada software house dengan Flow-Shop Problem (FSP) menggunakan algoritma Artificial Bee Colony (ABC). Dimana dalam FSP dibutuhkan suatu solusi untuk menyelesaikan suatu job/task dengan meminimalkan total cost yang dikeluarkan. Terdapat constraint yang perlu diperhatikan dalam objek permasalahan penelitian ini, yaitu lama waktu penyelesaian keseluruhan projek software yang tidak pasti. Dalam penelitian ini akan disusun sebuah representasi solusi yaitu berupa urutan pengerjaan projek dengan total waktu pengerjaan yang minimum. Pengujian akan dilakukan dengan tiga kali percobaan untuk setiap kondisi uji coba, yaitu uji coba batas parameter iterasi dan uji coba batas parameter limit. Dari hasil pengujian didapatkan bahwa penggunaan algoritma yang dibahas dalam penelitian ini bisa mengurangi waktu pengerjaan jika jumlah iterasi dan jumlah colony diperbesar.
\end{abstract}

Kata kunci: optimasi, flow-shop problem, artificial bee colony, swarm intelligence, meta-heuristik.

\begin{abstract}
This research proposed an implementation related to software execution scheduling process at a software house with Flow-Shop Problem (FSP) using Artificial Bee Colony (ABC) algorithm. Which in FSP required a solution to complete some job/task along with its overall cost at a minimum. There is a constraint that should be kept to note in this research, that is the uncertainty completion time of its jobs. In this research, we will present a solution that is a sequence order of project execution with its overall completion time at a minimum. An experiment will be performed with 3 attempts on each experiment conditions, that is an experiment of iteration parameter and experiment of limit parameter. From this experiment, we concluded that the use of this algorithm explained in this paper can reduce project execution time if we increase the value of total iteration and total colony.
\end{abstract}

Keywords: optimization, flow-shop problem, artificial bee colony, swarm intelligence, meta-heuristic.

\section{PENDAHULUAN}

Scheduling atau penjadwalan merupakan pekerjaan untuk mengalokasikan sumber daya yang terbatas dari suatu pekerjaan untuk mengefisiensikan waktu pengerjaan (Garrido dkk., 1994). Job Shop Problem merupakan suatu permasalahan dimana dibutuhkan suatu solusi untuk menyelesaikan suatu job/task dengan meminimalkan total cost yang dikeluarkan. Pada penelitian ini, terdapat constraint yang perlu diperhatikan yaitu ketidakpastian waktu proses penyelesaian suatu job.

Ketidakpastian waktu proses penyelesaian tentunya berhubungan erat dengan bidang pekerjaan tertentu seperti software house, dsb. Untuk constraint pertama berupa masalah ketidakpastian dalam waktu pemrosesan, dapat diselesaikan menggunakan algorima kombinatorial Artificial Bee Colony.

Penulis menemukan salah satu penelitian yang berhubungan dengan konsep dasar dari penjadwalan.
Penelitian ini mendiskusikan permasalahan Constraint Satisfaction Problem (CSP) yang didasari oleh konsep slack untuk nilai dan variabel tertentu yang harus dilakukan oleh suatu operasi (Garrido dkk., 1994). Penelitian ini menyimpulkan bahwa metode heuristik dapat menyelesaikan beberapa jenis permasalahan yang sulit diselesaikan dengan menggunakan CSP tradisional.

Penelitian sebelumnya yang terkait dengan penjadwalan juga pernah dilakukan oleh Bruker dan Schile (Gao dkk., 2016) yang merupakan penggagas dalam penelitian tentang Flexible Job Shop Problem (FJSP) dengan mengajukan penelitian berupa algoritma polynomial untuk 2 jobs dan penggunaan mesin identik pada sebuah FJSP.

Penelitian lain dengan permasalahan FJSP dengan uncertaity processing time dan new job insertion pernah dilakukan oleh Gao, dkk. (2016) dengan menggunakan Artificial Bee Colony (ABC). Penelitian ini menggambarkan dan membandingkan 
beberapa metode solusi terbaru dan membahas strategi pengembangan. Tujuannya adalah untuk meminimalkan nilai dari fuzzy completion time. Pada penelitian yang menjadi rujukan penulis, penelitian tersebut menggunakan Two-stage Artificial Bee Colony (TABC) dengan beberapa pengembangan dan hasilnya menunjukkan bahwa metode tersebut mampu bersaing dengan beberapa metode yang sudah ada sebelumnya.

Dari latar belakang tersebut, kami mencoba menerapkan prinsip-prinsip tersebut dengan merubah domain permasalahan menjadi penjadwalan pengerjaan software. Penelitan ini penulis beri judul Optimasi Penjadwalan Pengerjaan Software pada Software House dengan Flow-Shop Problem Menggunakan Artificial Bee Colony. Penelitian ini menggunakan data pegerjaakn project yang statis sehingga lebih efisien jika tidak menggunakan twostage artificial bee colony, diharapkan penelitian yang penulis lakukan ini bisa mejadi rujukan pada penelitian-penelitian lain dengan topik yang berkaitan.

\section{DASAR TEORI}

\subsection{Data Penelitian Projek}

Penelitian ini menggunakan dataset yang didapat dari perusahaan software house GUMCODE, Malang, Jawa Timur. Data yang penulis peroleh berupa 10 daftar projek berserta timeline pengerjaan setiap projek. Data ini penulis konversikan kedalam satuan tabel dan bisa dilihat pada Tabel 2.1 berikut. Tabel ini menunjukkan lama pengerjaan setiap tahap pada suatu projek dalam satuan minggu.

Tabel 2.1 Dataset pengerjaan projek GUMCODE

\begin{tabular}{|c|c|c|c|c|}
\hline \multirow{2}{*}{$\begin{array}{c}\text { Projek } \\
\text { ke- } i\end{array}$} & \multicolumn{5}{|c|}{ Pengerjaan } \\
\cline { 2 - 5 } & $\begin{array}{c}\text { Tahap } \\
1\end{array}$ & $\begin{array}{c}\text { Tahap } \\
2\end{array}$ & $\begin{array}{c}\text { Tahap } \\
3\end{array}$ & $\begin{array}{c}\text { Tahap } \\
4\end{array}$ \\
\hline 1 & 2 & 2 & 1 & 2 \\
\hline 2 & 1 & 3 & 3 & 4 \\
\hline 3 & 6 & 9 & 2 & 3 \\
\hline 4 & 1 & 4 & 3 & 2 \\
\hline 5 & 4 & 4 & 1 & 2 \\
\hline 6 & 3 & 1 & 0 & 0 \\
\hline 7 & 1 & 2 & 7 & 3 \\
\hline 8 & 1 & 3 & 4 & 4 \\
\hline 9 & 1 & 2 & 8 & 1 \\
\hline 10 & 1 & 1 & 5 & 2 \\
\hline
\end{tabular}

\subsection{Estimasi Pengerjaan Software}

Estimasi Pengerjaan Software merupakan topik yang sulit. Steve McConnell menyebutnya Black Art, sehingga dia mengarang buku yang sangat bagus tentang topik ini, judulnya Software Estimation, Demystifying the Black Art. Menurut Steve, dalam membuat estimasi, ada 3 metode yang dilakukan, yaitu count, compute, judge (McConnell, 2006).

Karakteristik perangkat lunak tentunya memberikan kendala yang tidak sedikit terhadap estimasi yang akan dilakukan. Kerumitan dari perangkat lunak tersebut dan hal lain yang tidak kasat mata, serta sumber daya manusia pengembang perangkat lunak tidak bisa diperkirakan secara mutlak secara mekanistik seperti mesin.

\subsection{Flow-Shop Problem}

Dalam flow-shop scheduling problem, terdapat sejumlah $n$ job dan $m$ mesin, dimana setiap job harus diproses pada setiap mesin mulai dari mesin 1 sampai mesin $m$ secara berurutan. Dengan kondisi seperti ini, tentunya akan muncul buffer dengan kapasitas yang tidak terbatas diantara mesin (Khorasanian, 2017). Pada permasalahan FSP ini, dapat diartikan dengan bagaimana membuat urutan pekerjaan, sehingga waktu yang dibutuhkan untuk menyelesaikan semua pekerjaan dapat diminimalkan.

\subsection{Algoritma Artificial Bee Colony}

\subsubsection{Inisialisasi Parameter dan Populasi}

Parameter yang harus diinisialisasi yaitu:

- Data Kasus : merupakan data pekerjaan apa saja yang harus dilakukan.

- Colony Size : jumlah Employee Bee ditambah dengan Onlooker Bee (Cholissodin, 2016).

- Maksimum Iterasi : merupakan banyaknya iterasi yang dilakukan.

- Limit : batas jumlah populasi yang kualitasnya tidak meningkat pada suatu iterasi.

- $\quad$ Number of sequence (NSE) : merupakan batasan banyak sequence dalam neighborhood operator.

Untuk melakukan inisialisasi populasi dapat dengan cara merandom urutan project yang harus dikerjakan, kemudian menghitung nilai makespan dan nilai fitness. Nilai makespan dapat dihitung dengan menggambarkan gantt-chart.

\subsubsection{Gantt Chart}

Perhitungan nilai makespan dilakukan menggunakan gantt-chart. Berikut ini penulis contohkan perhitungan makespan menggunakan gantt-chart dengan projek dan task yang ditunjukkan pada Tabel 2.2 dibawah ini, dengan urutan pengerjaan 2, 3, 1, 4: 
Tabel 2.2 Projek dan task

\begin{tabular}{|c|c|c|}
\hline \multirow{2}{*}{ Project } & \multicolumn{2}{|c|}{ Task } \\
\cline { 2 - 3 } & $\mathbf{1}$ & $\mathbf{2}$ \\
\hline 1 & 2 & 3 \\
\hline 2 & 2 & 2 \\
\hline 3 & 5 & 2 \\
\hline 4 & 1 & 1 \\
\hline
\end{tabular}

Tabel di atas bisa kita gambarkan seperti gantt-chart pada Gambar 2.1 yang menunjukkan makespan dari bee tersebut adalah 13.

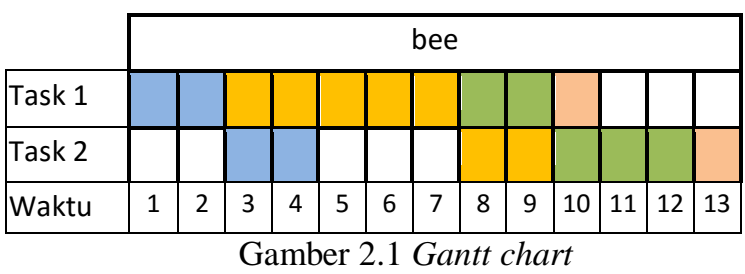

Berdasarkan contoh kasus, project yang pertama kali dikerjakan adalah project nomor 2 dimana pada project ini task 1 dan task 2 diselesaikan dalam 2 pekan dan task yang berbeda dari project yang sama tidak boleh dikerjakan dalam pekan yang sama sehingga pada kolom pekan pertama sampai pekan keempat diblock dengan warna biru muda.

Hal yang sama dilakukan juga untuk project 3. Pada task 1 , project 3 membutuhkan waktu 5 pekan untuk pengerjaannya. Oleh karena itu, task 2 dari project 3 baru dapat dijalankan pada pekan ke- 8 . Begitu seterusnya sampai project yang terakhir.

\subsubsection{Rumus Fitness}

Rumus fitness merupakan suatu rumus yang digunakan sebagai tolak ukur baik atau tidaknya urutan pengerjaan projek yang sedang diteliti, rumus fitness dapat dilihat pada persamaan 2.1 sebagai berikut:

$$
\text { fitness }=1 / \mathrm{C}
$$

$C=$ cost atau dimana dalam penelitian ini cost yang digunakan adalah total makespan dari gantt-chart.

\subsubsection{Fase Employeed Bee}

Pada fase ini dilakukan update populasi untuk setiap Employeed Bee dengan menggunakan neighborhood operator, yang terdiri dari swap operator (SO) dan swap sequence (SS). Kemudian hitung fitness nya, jika solusi yang baru lebih baik dari pada yang lama maka gantikan solusi lama dengan solusi baru, jika tidak tambahkan nilai trial dengan 1. Langkah-langkahnya sebagai berikut:

Swap Operator dapat dihitung dengan cara melakukan pergantian posisi antara 2 operasi. Solusi baru dapat dihitung dengan rumus (Cholissodin, 2016):

$$
x_{i}=x_{i}+S O
$$

Swap Squences dapat dihitung dengan cara melakukan perhitungan SO sejumlah NSE, perhitungan SS dilakukan pada semua Employeed Bee. Solusi didapatkan dengan mencari nilai fitness terbaik pada setiap perhitungan SS, solusi baru dapat dihitung dengan rumus:

$$
\begin{aligned}
& x_{i}=x_{i}+\mathrm{SS} \\
& x_{i}=x_{i}+\left(\mathrm{SO}_{1}, \mathrm{SO}_{2}, \mathrm{SO}_{3}, \ldots, \mathrm{SO}_{n}\right) \\
& n=\text { banyaknya SS, kemudian hitung nilai }
\end{aligned}
$$
probabilitas setiap Employeed Bee dengan rumus (Cholissodin, 2016):

$$
\operatorname{Prob}_{i}=\frac{\text { fitness }\left(x_{i}\right)}{\sum_{k=1}^{S} \operatorname{fitness}\left(x_{k}\right)}
$$

\subsubsection{Fase Onlooker Bee}

Untuk setiap Onlooker Bee didapatkan dengan cara memilih solusi yang ada pada Employeed Bee, dengan teknik seleksi roulette wheel.

Untuk menentukan solusi yang baru, dapat dilakukan dengan menggunakan neighborhood operator, yang terdiri dari insert operator (IO) dan insert sequence (IS). Kemudian hitung fitness-nya, jika solusi yang baru lebih baik dari pada yang lama maka gantikan solusi lama dengan solusi baru, jika tidak tambahkan nilai trial dengan 1. Langkahlangkahnya sebagai berikut:

Insert Operator dapat dihitung dengan cara melakukan insert, misalnya $\mathrm{IO}(1,3)$ artinya melakukan insert operasi ke 3 kedepan operasi 1. Solusi baru dapat dihitung dengan rumus (Cholissodin, 2016):

$$
x i=x i+I O
$$

Insert Squences dapat dihitung dengan cara melakukan perhitungan IO sejumlah NSE, perhitungan IS dilakukan pada semua Onlooker Bee. Solusi didapatkan dengan mencari nilai fitness terbaik pada setiap perhitungan IS, Solusi baru dapat dihitung dengan rumus:

$$
\begin{aligned}
& x_{i}=x_{i}+I S \\
& x_{i}=x_{i}+\left(I O_{1}, I O_{2}, I O_{3}, \ldots, I O_{n}\right) \\
& n=\text { banyaknya IS }
\end{aligned}
$$

\subsubsection{Fase Scout Bee}

Setelah melalui dua fase sebelumnya, yaitu Employeed Bee dan Onlooker Bee, maka langkah selanjutnya yaitu perhitungan kualitas dari masingmasing Employeed Bee. Jumlah Scout Bee dalam fase 
ini bersifat dinamis, tergantung pada jumlah employeed yang telah melebihi limit.

Apabila limit dari Bee yang melakukan Improvement Solution melebihi maksimum limit yang ditetapkan, maka solusi pada Bee tersebut dihilangkan dan digantikan dengan solusi baru yang dibuat secara random, kemudian memperbarui fitness yang dihasilkan, dan menyetel ulang limit menjadi 0.

\section{PERANCANGAN DAN IMPLEMENTASI}

\subsection{Perancangan Alur Proses Algoritma}

Perancangan alur proses algoritma ini kami adaptasi dari penjelasan yang telah dijelaskan pada bagian dasar teori, dimana rancangannya dapat dilihat pada Gambar 3.1.

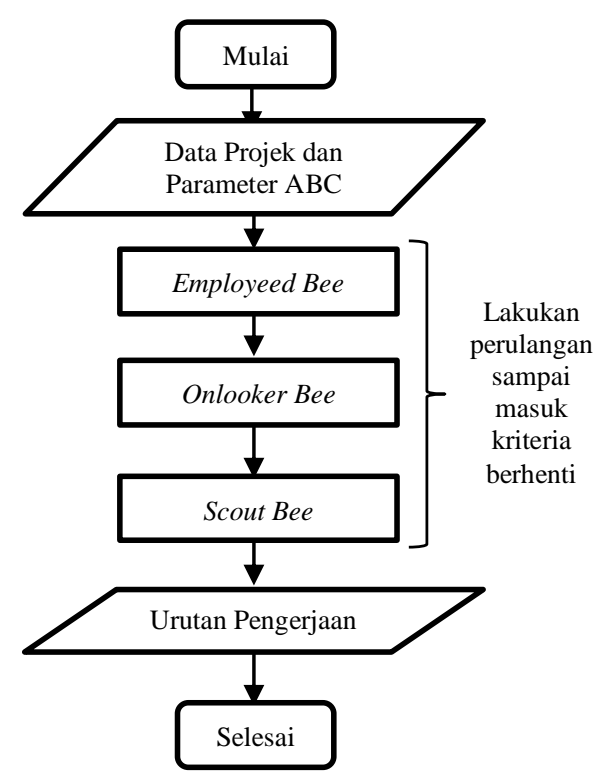

Gambar 3.1 Diagram Alur Proses Optimasi Penjadwalan

Dimana representasi solusinya adalah indeks urutan pengerjaan projek, agar lebih jelasnya dapat dilihat contoh representasi solusi individu pada Gambar 3.2.

\begin{tabular}{|c|c|c|c|c|}
\hline & $<-----\mid$ & represento & olus & -------> \\
\hline $\mathrm{P} 1=$ & [ Projek 1, & Projek 2, & $\ldots$, & Projek $i]$ \\
\hline
\end{tabular}

Gambar 3.2 Contoh representasi solusi individu

\subsection{Perancangan Uji Coba}

Perancangan uji coba ini dilakukan untuk mengevaluasi dan menganalisis hasil yang dihasilkan, dimana akan dilakukan 2 proses uji coba yaitu sebagai berikut:

\subsubsection{Uji Coba Parameter Iterasi}

Pada uji coba ini, penulis mencari nilai fitness yang optimal dengan melakukan perubahan sebanyak
5 kali terhadap jumlah iterasi. Percobaan ini dilakukan untuk melihat pengaruh jumlah iterasi terhadap peningkatan nilai fitness.

\subsubsection{Uji Coba Parameter Limit}

Pada uji coba ini, penulis mencari nilai fitness yang optimal dengan melakukan perubahan sebanyak 5 kali terhadap nilai limit. Percobaan ini dilakukan untuk melihat pengaruh nilai limit terhadap peningkatan nilai fitness.

\subsection{Implementasi}

Implementasi pada penelitian ini dilakukan dengan mengikuti dasar teori serta perancangan yang telah dijelaskan pada poin 2 dan 3 .

Tabel 3.3 Prosedur pengerjaan FSP-ABC

Tahap 1: Membuat inisialisasi bee untuk tahap employeed bee secara acak sebanyak populasi

Tahap 2: Lakukan evaluasi fitness pada setiap bee dalam populasi

Tahap 3: Lakukan improvement dengan menggunakan swap operator (SO) pada bee inisialisasi, kemudian evaluasi fitness-nya kembali Tahap 4: Lakukan improvement dengan menggunakan swap sequence (SS) pada bee hasil SO, kemudian evaluasi fitness-nya kembali Tahap 5: Lakukan selection dengan menggunakan roulette wheel selection (RWS) pada bee hasil SS hingga terbentuk bee baru hasil seleksi sebanyak populasi sebagai bee untuk tahap onlooker bee Tahap 6: Lakukan improvement dengan menggunakan insertion operator (IO) pada bee hasil RWS, kemudian evaluasi fitness-nya kembali Tahap 7: Lakukan improvement dengan menggunakan insertion sequence (IS) pada bee hasil IO, kemudian evaluasi fitness-nya kembali Tahap 8: Ambil individu dengan nilai fitness terbaik pada bee hasil IS sebagai global best/solusi terbaik

Tahap 9: Bandingkan nilai fitness antara bee inisialisasi dengan bee hasil IS, dengan kondisi:

- Jika maksimum nilai trial bee melebihi limit dan bee tidak mengalami perbaikan maka reset nilai trial menjadi 0 , dan acak kembali urutan pengerjaan projeknya secara acak seperti pada tahap inisialisasi

- Jika maksimum nilai trial bee melebihi limit dan bee mengalami perbaikan maka reset nilai trial menjadi 0 , dan biarkan urutan pengerjaan projek pada bee tersebut seperti pada hasil IS

- Jika maksimum nilai trial bee belum melebihi limit maka nilai trial tidak perlu di-reset dan biarkan urutan pengerjaan 


\section{projek pada bee tersebut seperti pada hasil IS}

Kriteria berhenti dari sistem ini akan dilakukan sebanyak maksimum iterasi. Iterasi akan dilakukan sampai kriteria berhenti terpenuhi, dan selama belum terpenuhi, maka akan mengulang langkah Tahap 3.

\section{PENGUJIAN DAN ANALISIS}

\subsection{Pengujian Parameter Iterasi}

Pengujian parameter iterasi ini menggunakan jumlah colony sebesar 3 dan nilai limit diambil dari nilai terkecil pada pengujian parameter limit, yaitu 5 . Berdasarkan hasil pengujian pada Tabel 4.1, nilai rata-rata fitness terkecil didapat pada iterasi 50.

Sementara itu, rata-rata nilai fitness terbesar bisa ditemukan pada saat iterasi 60. Sehingga jumlah iterasi bisa ditetapkan 60 agar mendapatkan nilai fitness maksimal.

Tabel 4.1 Pengujian Parameter Iterasi

\begin{tabular}{|c|c|c|c|c|}
\hline \multicolumn{5}{|c|}{ Uji Coba Batas Parameter Iterasi } \\
\hline \multirow{2}{*}{ Iterasi } & \multicolumn{3}{|c|}{ Nilai Fitness Percobaan ke- $i$} & \multirow{2}{*}{$\begin{array}{c}\text { Rata - } \\
\text { Rata } \\
\text { Fitnes }\end{array}$} \\
\hline & 1 & 2 & 3 & \\
\hline 10 & 0.0159 & 0.0154 & 0.0159 & 0.0157 \\
\hline 20 & 0.0156 & 0.0152 & 0.0141 & 0.0150 \\
\hline 30 & 0.0156 & 0.0161 & 0.0156 & 0.0158 \\
\hline 40 & 0.0159 & 0.0152 & 0.0154 & 0.0155 \\
\hline 50 & 0.0159 & 0.0139 & 0.0139 & 0.0146 \\
\hline 60 & 0.0161 & 0.0167 & 0.0159 & 0.0162 \\
\hline
\end{tabular}

Berikut ini adalah grafik yang menggambarkan tabel di atas.

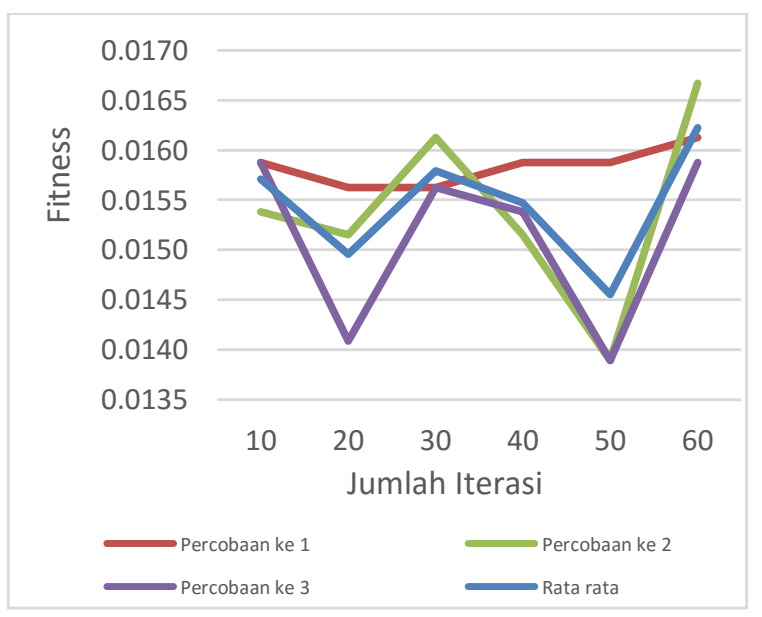

Gambar 4.1 Pengujian Parameter Iterasi

\subsection{Pengujian Parameter Limit}

Pengujian parameter limit ini menggunakan jumlah colony sebesar 3 dan nilai iterasi diambil dari iterasi dengan fitness terbesar ada pengujian paramter iterasi, yaitu 60. Berdasarkan hasil pengujian pada Tabel 4.2, nilai rata-rata fitness terkecil didapat pada percobaan dengan limit 30 .

Sementara itu, rata-rata nilai fitness terbesar bisa ditemukan pada saat nilai limit 5. Sehingga nilai iterasi bisa ditetapkan 5 agar mendapatkan nilai fitness maksimal.

Tabel 4.2 Pengujian Parameter Limit

\begin{tabular}{|c|c|c|c|c|}
\hline \multicolumn{5}{|c|}{ Uji Coba Batas Parameter limit } \\
\hline \multirow{2}{*}{$\underset{t}{\operatorname{limi}}$} & \multicolumn{3}{|c|}{ Nilai Fitness Percobaan ke- $i$} & \multirow{2}{*}{$\begin{array}{l}\text { Rata - } \\
\text { Rata } \\
\text { Fitness }\end{array}$} \\
\hline & 1 & 2 & 3 & \\
\hline 5 & 0.0161 & 0.0167 & 0.0159 & 0.0162 \\
\hline 10 & 0.0159 & 0.0164 & 0.0159 & 0.0160 \\
\hline 15 & 0.0159 & 0.0161 & 0.0156 & 0.0159 \\
\hline 20 & 0.0152 & 0.0159 & 0.0156 & 0.0155 \\
\hline 25 & 0.0167 & 0.0156 & 0.0161 & 0.0161 \\
\hline 30 & 0.0152 & 0.0159 & 0.0154 & 0.0155 \\
\hline
\end{tabular}

Berikut ini adalah diagram yang menggambarkan tabel di atas.

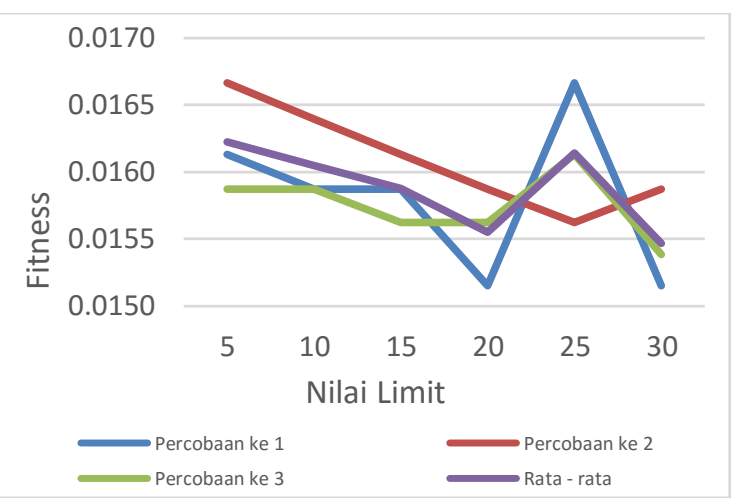

Gambar 4.2 Pengujian Parameter Limit

Oleh karena itu, untuk mendapatkan nilai fitness yang maksimal, kita bisa mengecilkan nilai limit dan memperbesar nilai iterasi.

\section{KESIMPULAN DAN SARAN}

Artificial bee colony dengan flow shop problem bisa digunakan untuk menyelesaikan permasalahan penjadwalan pengerjaan project pada software house GUMCODE. Penjadwalan tersebut diuji dengan asumsi terdapat 4 mesin atau 4 tahap dalam pengerjaan setiap projek.

Pengujian ini menyimpulkan bahwa parameter yang optimal agar dapat menghasilkan nilai fitness terbaik adalah parameter dengan nilai iterasi 60 dan 
nilai limit 5. Dengan kata lain, semakin besar nilai iterasi dan semakin kecil nilai limit, maka nilai fitness akan semakin baik.

Penelitian ini dapat dikembangkan dengan job shop scheduling yang lain ataupun bisa ditambahkan dengan pengunaan fuzzy seperti penelitian yang dilakukan oleh (Gao dkk., 2016).

\section{DAFTAR PUSTAKA}

CHOLISSODIN, I. (2016). Modul Swarm Intelligence - Semester Ganjil 2016-2017.

GAO, KAI ZHOU. dkk., 2016. Artificial bee colony algorithm for scheduling and rescheduling fuzzy flexible job shop problem with new job insertion. Knowledge-Based Systems 109 (2016) 1-16.

KARTHIKEYAN, A., MANIKANDAN, K. \& SOMASUNDARAM, P., 2016. Economic Dispatch of Microgrid with Smart Energy Storage Systems using Particle Swarm Optimization. $2016 \quad$ International Conference on Computation of Power, Energy Information and Communication (ICCPEIC).

KHORASANIAN, D. \& MOSLEHI, G., 2017. Twomachine flow shop scheduling problem with blocking, multi-task flexibility of the first machine, and preemption. Computers and Operation Research, 79(August 2016), pp.94-108. Available at: http://dx.doi.org/10.1016/j.cor.2016.09.023.

MCCONNELL, S., Software Estimation, Demystifying the Black Art. Washington, 2006. 